\title{
Bilateral Fallopian Canal Meningocele: Case Report and Literature Review
}

\section{Vito Pontillo* and Nicola Quaranta}

Otolaryngology Unit, Department of BMS, Neuroscience and Sensory Organs, University of Bari, Bari, Italy

*Corresponding Author: Vito Pontillo, Otolaryngology Unit, Department of BMS, Neuroscience and Sensory Organs, University of Bari, Bari, Italy.
Received: May 25, 2021

Published: June 23, 2021

(C) All rights are reserved by Vito Pontillo and Nicola Quaranta.

\section{Abstract}

Meningocele of the fallopian canal is assumed to be related to a defective ossification of the Facial Canal and to a subsequent dilatation of the subarachnoid space within this canal.

We bring our personal experience with a singular case of bilateral fallopian canal meningocele of a 48-year-old woman with a history of right otogenic meningitis. Considering the high risk of iatrogenic CSF fistula or facial palsy, it was decided to proceed by exclusively treating the right meningocele, while monitoring the left side. We carried out a subsequent analysis of the literature in order to verify the accuracy of our strategy.

A comprehensive search was conducted in PubMed from January 1, 1966, through December 31, 2020. To the best of our knowledge, 25 cases of fallopian canal meningocele were reported in the literature thus far, and only one of them with bilateral presentation. All the surgical strategies were analysed.

Surgical approach to this condition must be tailored to the single case, especially in the unlikely circumstance of bilateral presentation. We propose our treatment strategy to this rare condition, in the lights of the literature debate and our personal experience. Keywords: Bilateral; Fallopian Canal; Facial Canal; Meningocele

\section{Abbreviations}

CSF: Cerebrospinal Fluid; IIH: Idiopathic Intracranial Hypertension; HRCT: High-Resolution Computed Tomography; CT: Computed Tomography; MRI: Magnetic Resonance Imaging; SP: Subtotal Petrosectomy; MFC: Middle Fossa Craniotomy; PM: Posterior Mastoidectomy; IAC: Internal Auditory Canal; FP: Facial Palsy; SCM: Sternocleidomastoid Muscle; CI: Cochlear Implantation; VPS: Ventriculo-Peritoneal Shunt

\section{Background}

Meningocele of the fallopian Canal has been rarely described. To our knowledge, only 25 cases have been reported in literature so far, including only one case with bilateral presentation [1-16].
These lesions, also known as fallopian canal arachnoid cysts, are assumed to be related to a defective ossification of the Facial Canal and to a subsequent dilatation of the subarachnoid space within this canal [17].

Surgery is challenging and associated with high morbidity, particularly facial nerve injury. The choice between the different treatment strategies is still debated.

We report the unique case of a patient with bilateral fallopian Canal meningocele discovered after a single episode of otogenic meningitis and we review the different treatment strategies reported in literature. 


\section{Case Presentation}

A 48-year-old woman presented to our Centre in May 2014, complaining bilateral hearing loss and right auricular fullness. No otorrhea/rhinorrhoea or dizziness were complained. No history of associated inner ear malformations, oto-neurosurgery or head trauma was reported.

Her pertinent medical history began with an episode of meningitis occurred 3 months before in course of a right-sided acute otitis media; at that time the patient was hospitalized in another medical unit where a lumbar puncture with CSF culture (positive for str. Pneumoniae) and an appropriate medical therapy were performed. No CSF leak from the nose or the ear was reported.

Physical examination revealed bilateral intact and normal-looking tympanic membranes and no signs of CSF leak. Facial nerve function and the rest of the cranial nerve examination was normal. No vestibular, oculomotor or cerebellar abnormalities were noted. She had a normal BMI and presented no signs of Idiopathic Intracranial Hypertension (IIH).

The pure tone audiogram showed a mild to moderate mixed hearing loss with type A tympanogram and absent stapedial reflex on the right side; the left ear presented a mild to moderate sensorineural hearing loss with type A tympanogram and normally elicited stapedial reflexes.

Axial High-Resolution Computed Tomography (HRCT) demonstrated the presence of a right-sided well-defined soft-tissue density mass localized in the epitympanic space and involving the first genu of the facial nerve. On coronal images the mass appeared to be centred on the geniculate ganglion fossa, seemingly in continuity with the middle cranial fossa. A smaller soft-tissue density lesion centred on the left geniculate ganglion was also detected (Figure 1). CT findings were consistent with the diagnostic hypothesis of a bilateral fallopian Canal meningocele or a congenital cholesteatoma.

Because of the previous meningitis episode and then the suspect of an unrecognized CSF leak, a right mastoidectomy with atticoantrotomy was performed. No signs of inflammatory or cholesteatomatous disease of the middle ear were found, while a little glistening and pulsatile mass with the appearance of a meningocele was identified in the area of the geniculate ganglion. Considering

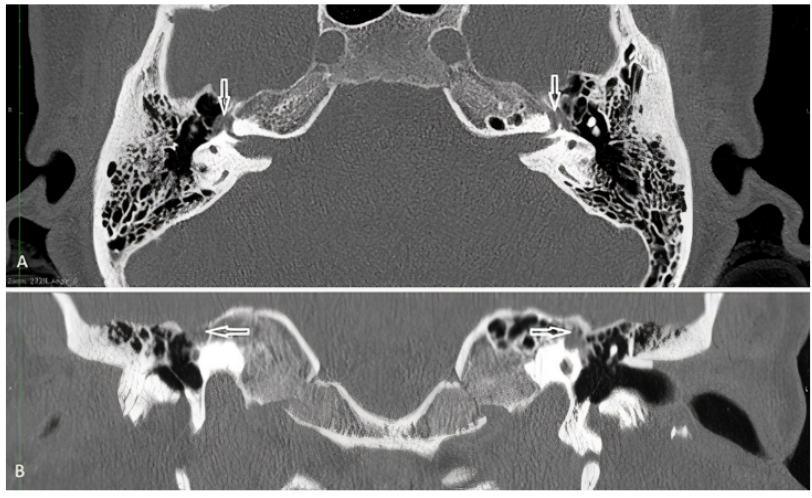

Figure 1: (A) Axial high-resolution CT scan showing on the right side a soft-tissue density mass localized in the epitympanic space, in the region of the first genu of the facial nerve; a smaller lesion is visible on the left side in the same area. (B) On coronal images the right mass was centred on the geniculate ganglion fossa and seemed to be in continuity with the middle cranial fossa; on the left side the overlying bone was not eroded.

the small size of the meningocele and the high risk of iatrogenic CSF fistula or facial palsy, it was decided to exclusively cover the meningocele with an autologous temporalis fascia.

A post-operative T2 3D MRI showed the presence of a hyperintense signal in the area of both the geniculate ganglions (Figure 2) and the absence of any indirect signs of IIH.

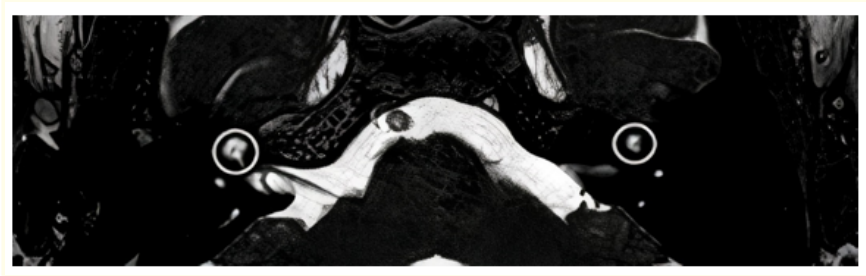

Figure 2: Axial T2 3D MR image showing a bilateral hyperintense signal in the area of the geniculate ganglion. The facial nerve is evident within the fluid. 
In consideration of the subsisting risk of new meningitis episodes, a careful risk-benefit assessment was pursued. The very small size of the left lesion, together with the long-term asymptomatic previous history and the absence of CSF leak and of any anatomic or pathologic susceptibility to inflammatory middle ear disease, lead us to undertake only a strict radiological and clinical follow-up. The patient was given a pneumococcal vaccine and appropriately educated of the need of immediate intervention in case of headache with fever. To this day, 6 years after surgery, she remains asymptomatic, no new episodes of meningitis have occurred, and her hearing threshold is unchanged.

All procedures were in accordance with the ethical standards of the institutional research committee and with the 1964 Helsinki Declaration and its later amendments or comparable ethical standards. Our Ethical Committee has been informed of the retrospective data collection. The patient has given her consent for publication of this case report and any accompanying images.

\section{Literature Review}

Methods

A comprehensive search was conducted in PubMed from January 1, 1966, through December 31, 2020, using the following search terms: ("facial canal"[All fields] OR "geniculate"'[All fields] OR "fallopian canal""[All fields]) AND ("meningocele"'"[All fields] OR "csf leak""[All fields] OR "cerebrospinal fluid"'[All fields] OR "arachnoid cyst""[All fields]) AND english [lang]. The research was then implemented by a careful investigation in the bibliographies of the previously found papers.

To the best of our knowledge, 16 publications reported about only 25 cases of fallopian canal meningocele thus far (Table 1), and only one of them with bilateral presentation [13]. In the following paragraphs we describe the $26^{\text {th }}$ case in general, but only the second bilateral fallopian canal meningocele recorded to date.

We can certainly speculate that the two cases reported by Petrus., et al. in 1999 [6] correspond with those described by Foyt., et al. in 2000 [7], since they have in common institutional information and clinical contents. Hence, they have been considered as a unique work in table 1. Besides, the case reported by van La Parra., et al. in 2007 [9] is limited to a radiologic assessment, while the one described by Zhang., et al. in 2011 [12] derives from an autop- tic study; for this reason, these two cases have not been taken into consideration for the evaluation of surgery outcomes in this review, but only for an epidemiologic and symptomatic assessment.

\section{Results}

The mean age at diagnosis was 27 years (range 2 - 73) and the gender was homogenous (13 women, 11 men).

Regarding clinical presentation, pre-operatively CSF leakage had occurred in 15 cases (60\%), meningitis in 8 cases $(32 \%)$ and facial palsy in 2 cases (16\%).

The 2 radiologic and autoptic reports, by van La Parra., et al. (2007) [9] and Zhang., et al. (2011) [12], were not considered for the assessment of the treatment strategies. Between the remaining 23 cases, 5 undertook a follow-up while a total of 18 patients underwent an average of 1.55 interventions, with a range of 1 to 5 operations.

Subtotal petrosectomy (SP) was performed in 3 cases, exclusive middle cranial fossa approach (middle fossa craniotomy, MFC) in 6 cases, combined transmastoid and middle fossa approach in one case and exclusive transmastoid approach (posterior mastoidectomy, PM) in 8 cases, 3 of which resulting only in diagnostic exploration, without any repair.

Post-operative complications occurred in 4 patients: 1 case of facial paresis after PM, 2 cases of facial palsy and 1 case of postural headaches after MFC.

A second revision surgery was undertaken in 6 cases after primary surgery: in 4 subjects for CSF leakage persistence/recurrence (in 2 cases after PM, in 1 case after MFC and in 1 case after combined approach), and for meningitis episodes after 2 cases of MFC.

The 3 cases of primary SP remained uneventful, while 33\% of revision SPs presented a CSF leak recurrence. No post-operative complications have been reported after SP.

\section{Discussion}

Herniation of meningeal tissue into the temporal bone through a bony defect is a rare but potentially life-threatening condition [18]. Temporal bone defects that lead to meningeal herniation are usually acquired and most commonly due to chronic otitis media, 


\begin{tabular}{|c|c|c|c|c|c|c|c|c|c|c|c|c|c|}
\hline Case & Source & $\begin{array}{l}\text { Years } \\
\text { (Gen- } \\
\text { der) }\end{array}$ & Side & $\begin{array}{c}\text { Meningi- } \\
\text { tis }\end{array}$ & $\begin{array}{l}\text { Facial } \\
\text { palsy }\end{array}$ & $\begin{array}{c}\text { CSF } \\
\text { leak- } \\
\text { age }\end{array}$ & Diagnosis & $\begin{array}{c}\text { Surgical } \\
\text { Approach }\end{array}$ & Repair & $\begin{array}{c}\text { Lumbar } \\
\text { drain }\end{array}$ & $\begin{array}{l}\text { Postop- } \\
\text { erative } \\
\text { compli- } \\
\text { cations }\end{array}$ & $\begin{array}{l}\text { Follow- } \\
\text { up time } \\
\text { (months) }\end{array}$ & $\begin{array}{l}\text { Recur- } \\
\text { rences }\end{array}$ \\
\hline 1 & $\begin{array}{c}\text { Harrington } \\
\text { and Birk } \\
\text { (1967) }\end{array}$ & $9(\mathrm{~F})$ & Left & $\begin{array}{c}\text { Yes (5 } \\
\text { episodes) }\end{array}$ & No & Yes & $\begin{array}{c}\text { Pantopaque } \\
\text { cisternog- } \\
\text { raphy }\end{array}$ & $\begin{array}{l}\text { 1) PM } \\
\text { 2) Revi- } \\
\text { sion PM }\end{array}$ & $\begin{array}{c}\text { Bone chips } \\
\text { and gelfoam } \\
\text { Middle ear } \\
\text { obliteration } \\
\text { with tempo- } \\
\text { ralis muscle }\end{array}$ & $\begin{array}{l}\text { Unspeci- } \\
\text { fied }\end{array}$ & No & 18 & $\begin{array}{c}\text { Persistent } \\
\text { rhinorrhea } \\
\text { after the } \\
\text { first PM } \\
\text { (oval win- } \\
\text { dow fistula). } \\
\text { No recur- } \\
\text { rences after } \\
\text { revision PM }\end{array}$ \\
\hline 2 & $\begin{array}{l}\text { Gacek and } \\
\text { Leipzig } \\
\text { (1979) }\end{array}$ & $2(\mathrm{M})$ & Right & $\begin{array}{c}\text { Yes (3 } \\
\text { episodes) }\end{array}$ & No & Yes & & PM & $\begin{array}{c}2 \text { layers of } \\
\text { temporalis } \\
\text { muscle } \\
\text { fascia }+ \\
\text { temporalis } \\
\text { muscle graft }\end{array}$ & $\begin{array}{c}\text { Unspeci- } \\
\text { fied }\end{array}$ & No & 24 & No \\
\hline 3 & $\begin{array}{c}\text { Barcz., et al. } \\
\text { (1985) }\end{array}$ & $14(\mathrm{M})$ & Left & $\begin{array}{c}\text { Yes (4 } \\
\text { episodes) }\end{array}$ & No & Yes & CT scan & $\mathrm{PM}$ & $\begin{array}{c}\text { Temporalis } \\
\text { fascia }\end{array}$ & $\begin{array}{l}\text { Unspeci- } \\
\text { fied }\end{array}$ & $=\begin{array}{c}\text { Facial } \\
\text { paresis }\end{array}$ & None & - \\
\hline 4 & $\begin{array}{l}\text { Legent., et al. } \\
\text { (1989) }\end{array}$ & 7 (M) & Left & $\begin{array}{c}\text { Yes (1 } \\
\text { episodes) }\end{array}$ & No & Yes & CT scan & PM & $\begin{array}{c}\text { Temporalis } \\
\text { fascia, bone } \\
\text { paté and } \\
\text { fibrin glue }\end{array}$ & $\begin{array}{l}\text { Unspeci- } \\
\text { fied }\end{array}$ & No & 8 & No \\
\hline 5 & $\begin{array}{l}\text { Gray., et al. } \\
\text { (1995) }\end{array}$ & $31(\mathrm{~F})$ & Left & No & Yes & No & $\begin{array}{c}\text { CT scan + } \\
\text { MRI }\end{array}$ & $\begin{array}{l}\text { 1) } \mathrm{PM} \\
\text { 2) } \mathrm{MFC}\end{array}$ & $\begin{array}{c}\text { Only explo- } \\
\text { ration } \\
\text { The menin- } \\
\text { gocele was } \\
\text { gently re- } \\
\text { moved from } \\
\text { the facial } \\
\text { nerve }\end{array}$ & $\begin{array}{l}\text { Unspeci- } \\
\text { fied }\end{array}$ & No & $\begin{array}{l}\text { Unspeci- } \\
\text { fied }\end{array}$ & Unclear \\
\hline 6 & $\begin{array}{l}\text { Petrus., et al. } \\
\text { (1999) Foyt., } \\
\text { et al. (2000) }\end{array}$ & $34(\mathrm{M})$ & Right & $\begin{array}{c}\text { Yes (3 } \\
\text { episodes) }\end{array}$ & No & Yes & CT scan & MFC & $\begin{array}{c}\text { Temporalis } \\
\text { muscle graft }\end{array}$ & No & $\begin{array}{l}\text { HB II/Vl } \\
\text { FP (im- } \\
\text { proved } \\
\text { to I/VI) }\end{array}$ & 18 & No \\
\hline \multirow[t]{2}{*}{7} & $\begin{array}{c}\text { Petrus., } \text { et al. } \\
\text { (1999) }\end{array}$ & $5(\mathrm{M})$ & Left & No & No & Yes & \multirow{2}{*}{ Ct scan } & 1) $\mathrm{MFC}$ & $\begin{array}{c}\text { Temporalis } \\
\text { fascia }\end{array}$ & $\begin{array}{l}\text { Yes (5 } \\
\text { days) }\end{array}$ & No & $\begin{array}{l}\text { Unspeci- } \\
\text { fied }\end{array}$ & $\begin{array}{c}\text { CSF leak (11 } \\
\text { months after } \\
\text { the initial } \\
\text { repair) }\end{array}$ \\
\hline & $\begin{array}{c}\text { Foyt., et al. } \\
\quad(2000)\end{array}$ & & & & & & & $\begin{array}{l}\text { 2) Revi- } \\
\text { sion MFC }\end{array}$ & $\begin{array}{c}\text { Temporalis } \\
\text { muscle and } \\
\text { Surgical }\end{array}$ & & & & $\begin{array}{c}\text { No recur- } \\
\text { rences after } \\
\text { revision } \\
\text { MFC }\end{array}$ \\
\hline
\end{tabular}




\begin{tabular}{|c|c|c|c|c|c|c|c|c|c|c|c|c|c|}
\hline 8 & $\begin{array}{c}\text { Isaacson., et } \\
\text { al. (2002) }\end{array}$ & $37(\mathrm{M})$ & Left & $\begin{array}{c}\text { Yes (1 } \\
\text { episode) }\end{array}$ & \begin{tabular}{|c} 
Yes \\
(HB \\
III/VI)
\end{tabular} & Yes & $\begin{array}{c}\text { Ct scan + } \\
\text { MRI }\end{array}$ & $\begin{array}{l}\text { 1) PM } \\
\text { 2) Revi- } \\
\text { sion PM } \\
\text { 3) MFC } \\
\text { 4) SP } \\
\text { 5) Revi- } \\
\text { sion SP }\end{array}$ & $\begin{array}{c}\text { Bone paté, } \\
\text { fibrin } \\
\text { glue, and a } \\
\text { temporalis } \\
\text { muscle flap } \\
\text { Tempora- } \\
\text { lis fascia, } \\
\text { fibrin glue, } \\
\text { and several } \\
\text { pieces of } \\
\text { conchal } \\
\text { cartilage } \\
\text { The thinned } \\
\text { tegmen was } \\
\text { reinforced } \\
\text { with fascia } \\
\text { lata } \\
2 \text { large free } \\
\text { grafts of } \\
\text { SCM muscle } \\
\text { were added }\end{array}$ & Yes & No & 132 & $\begin{array}{c}\text { - Otorhinor- } \\
\text { rhea (after } \\
\text { PM and revi- } \\
\text { sion PM) } \\
\text { - Recurrent } \\
\text { meningitis } \\
\text { (2 episodes } \\
\text { after MFC } \\
\text { and } 1 \text { after } \\
\text { SP) } \\
\text { - CSF leak } \\
\text { in the neck } \\
\text { after revi- } \\
\text { sion SP. VPS } \\
\text { was pro- } \\
\text { posed, but } \\
\text { the patient } \\
\text { declined. } \\
\text { No further } \\
\text { recurrence } \\
\text { of menin- } \\
\text { gitis in the } \\
\text { following } 3 \\
\text { years. } \\
\end{array}$ \\
\hline 9 & $\begin{array}{c}\text { van la Parra., } \\
\text { et al. (2007) } \\
\text { - Radiologic } \\
\text { Study }\end{array}$ & - & - & No & Yes & Yes & $\begin{array}{c}\text { Ct scan + } \\
\text { MRI }\end{array}$ & $\begin{array}{l}\text { Unspeci- } \\
\text { fied }\end{array}$ & Unspecified & - & - & - & - \\
\hline 11 & $\begin{array}{c}\text { Mong., et al. } \\
\text { (2009) }\end{array}$ & $7(\mathrm{M})$ & Left & No & No & Yes & $\begin{array}{l}\text { CT cister- } \\
\text { nography }\end{array}$ & $\begin{array}{l}\text { 1) MFC } \\
\text { 2) Revi- } \\
\text { sion MFC }\end{array}$ & $\begin{array}{c}\text { Muscle, } \\
\text { fascial, and } \\
\text { bone graft } \\
\text { Repair of } \\
\text { multiple } \\
\text { pinpoint } \\
\text { lateral } \\
\text { cranial base } \\
\text { dehiscences }\end{array}$ & $\begin{array}{l}\text { Yes (re- } \\
\text { peated) }\end{array}$ & $\begin{array}{c}\text { HB VI/ } \\
\text { VI FP } \\
\text { (impro- } \\
\text { ved to } \\
\text { III/VI) }\end{array}$ & 24 & $\begin{array}{l}4 \text { separate } \\
\text { bouts of } \\
\text { meningitis } \\
\text { after revi- } \\
\text { sion MFC }\end{array}$ \\
\hline 12 & $\begin{array}{l}\text { Dhanasekar., } \\
\text { et al. (2010) }\end{array}$ & $9(\mathrm{M})$ & Right & $\begin{array}{l}\text { Yes (re- } \\
\text { current) }\end{array}$ & No & No & $\begin{array}{c}\text { CT scan + } \\
\text { MRI }\end{array}$ & $\begin{array}{c}\text { SP (+ Bilat } \\
\text { CI) }\end{array}$ & $\begin{array}{l}\text { Fascia and } \\
\text { fibrin glue }\end{array}$ & No & No & 24 & No \\
\hline
\end{tabular}




\begin{tabular}{|c|c|c|c|c|c|c|c|c|c|c|c|c|c|}
\hline 13 & $\begin{array}{l}\text { Zhang., et } \\
\text { al. (2011) } \\
\text { - Autoptic } \\
\text { Study }\end{array}$ & $71(F)$ & Left & No & No & No & - & - & - & & - & - & - \\
\hline 14 & $\begin{array}{l}\text { Allen and } \\
\text { Roland } \\
\text { (2013) }\end{array}$ & $39(\mathrm{~F})$ & $\begin{array}{l}\text { Bilat- } \\
\text { eral }\end{array}$ & No & No & Yes & $\begin{array}{c}\text { CT scan + } \\
\text { MRI }\end{array}$ & Right MF( & Unspecified & No & No & $\begin{array}{l}\text { Unspeci- } \\
\text { fied }\end{array}$ & No \\
\hline 15 & $\begin{array}{c}\text { Teufert and } \\
\text { Slattery } \\
(2013)\end{array}$ & $45(F)$ & Right & No & No & Yes & Ct scan & MFC & Unspecified & $\begin{array}{l}\text { Unspeci- } \\
\text { fied }\end{array}$ & No & $\begin{array}{l}\text { Unspeci- } \\
\text { fied }\end{array}$ & No \\
\hline 16 & & & $\begin{array}{c}\text { Un- } \\
\text { speci- } \\
\text { fied }\end{array}$ & No & No & No & $\begin{array}{c}\text { CT scan + } \\
\text { MRI }\end{array}$ & No & - & No & - & 63 & - \\
\hline 17 & & & $\begin{array}{c}\text { Un- } \\
\text { speci- } \\
\text { fied }\end{array}$ & No & No & No & $\begin{array}{c}\text { CT scan + } \\
\text { MRI }\end{array}$ & No & - & Yes & - & 38 & - \\
\hline 18 & & & $\begin{array}{c}\text { Un- } \\
\text { speci- } \\
\text { fied }\end{array}$ & No & No & Yes & $\begin{array}{c}\text { CT scan + } \\
\text { MRI }\end{array}$ & No & - & No & - & 111 & - \\
\hline 19 & & $\begin{array}{c}\text { Mean } \\
\text { age: } 46 \\
\text { (range } \\
14-73 \text { ) }\end{array}$ & $\begin{array}{c}\text { Un- } \\
\text { speci- } \\
\text { fied }\end{array}$ & No & No & Yes & $\begin{array}{c}\text { CT scan + } \\
\text { MRI }\end{array}$ & SP & $\begin{array}{l}\text { Middle ear } \\
\text { exclusion } \\
\text { using au- } \\
\text { tologous fat } \\
\text { and muscle }\end{array}$ & Yes & $\begin{array}{c}\text { Unspec- } \\
\text { ified }\end{array}$ & 108 & No \\
\hline 20 & $\begin{array}{c}\text { Sagardoy., et } \\
\text { al. (2017) }\end{array}$ & & $\begin{array}{l}\text { Un- } \\
\text { speci- } \\
\text { fied }\end{array}$ & Yes & Yes & No & $\begin{array}{c}\text { CT scan + } \\
\text { MRI }\end{array}$ & SP & $\begin{array}{l}\text { Middle ear } \\
\text { exclusion } \\
\text { using au- } \\
\text { tologous fat } \\
\text { and muscle }\end{array}$ & No & $\begin{array}{c}\text { Unspec- } \\
\text { ified }\end{array}$ & 107 & No \\
\hline 21 & & & $\begin{array}{l}\text { Un- } \\
\text { speci- } \\
\text { fied }\end{array}$ & No & No & No & $\begin{array}{c}\text { CT scan + } \\
\text { MRI }\end{array}$ & PM & $\begin{array}{c}\text { Removal } \\
\text { of choles- } \\
\text { teatoma and } \\
\text { exploration } \\
\text { of the cyst }\end{array}$ & No & - & 12 & - \\
\hline 22 & & $6 \mathrm{~F} / 3 \mathrm{M}$ & $\begin{array}{c}\text { Un- } \\
\text { speci- } \\
\text { fied }\end{array}$ & No & No & No & $\begin{array}{c}\text { CT scan + } \\
\text { MRI }\end{array}$ & PM & $\begin{array}{c}\text { Removal } \\
\text { of choles- } \\
\text { teatoma and } \\
\text { exploration } \\
\text { of the cyst }\end{array}$ & No & - & 4 & - \\
\hline 23 & & & $\begin{array}{l}\text { Un- } \\
\text { speci- } \\
\text { fied }\end{array}$ & No & No & No & $\begin{array}{c}\text { CT scan + } \\
\text { MRI }\end{array}$ & No & - & No & - & 2 & - \\
\hline 24 & & & $\begin{array}{l}\text { Un- } \\
\text { speci- } \\
\text { fied }\end{array}$ & No & No & No & $\begin{array}{c}\text { CT scan + } \\
\text { MRI }\end{array}$ & No & - & No & - & 115 & - \\
\hline
\end{tabular}




\begin{tabular}{|c|c|c|c|c|c|c|c|c|c|c|c|c|c|}
\hline 25 & $\begin{array}{c}\text { Dey., et al. } \\
\text { (2019) }\end{array}$ & $53(F)$ & Right & No & No & Yes & CT scan & $\begin{array}{l}\text { 1) } \mathrm{PM}+ \\
\mathrm{MFC} \\
\text { 2) } \mathrm{SP}\end{array}$ & $\begin{array}{c}\text { Temporalis } \\
\text { fascia and } \\
\text { muscle }+ \\
\text { biological } \\
\text { dural sub- } \\
\text { stitute }\end{array}$ & Yes & No & 9 & $\begin{array}{l}\text { Right otor- } \\
\text { rhea after } \\
\text { the first } \\
\text { surgery } \\
\text { No recur- } \\
\text { rences after } \\
\text { SP }\end{array}$ \\
\hline
\end{tabular}

HB=House-Brackmann scale; CT=Computed Tomography; MRI=Magnetic Resonance Imaging; PM=Postauricular Mastoidectomy; MFC=Middle Fossa Craniotomy; SP=Subtotal Petrosectomy; FP=Facial Palsy; CSF=Cerebrospinal Fluid; SCM=Sternocleidomastoid muscle; CI=Cochlear Implantation; VPS=Ventriculo-Peritoneal Shunt

Table 1: Literature review of fallopian canal meningocele.

previous oto-neurosurgical procedures, traumatic temporal bone fracture, neoplasms, or radiation exposition [19]. In 25\% of cases [20] none of the aforementioned causes can be found, and meningoceles are then considered to be 'spontaneous' or 'idiopathic'.

Concerning spontaneous meningoceles, some Authors have hypothesized the congenital defect as the "first event" leading to temporal bone meningoceles, whereas the "second event" could be a sudden change in intracranial pressure (for example due to excessive straining, head trauma, etc.), or the formation of arachnoid granulations, or even a high intracranial pressure occurring during adulthood [20,21]. A chronic increase of intracranial pressure, especially in obese patients, may be the exclusive etiologic factor. In fact, the continuous CSF pulsation against the bone may result in bony erosions, that may culminate over time in obvious bony defects [22]. A persistent increased intra-abdominal pressure, resulting in a decreased venous return and secondarily leading to increased intracranial pressure, has been hypothesized as the main pathogenic mechanism in overweight patients [23].

Phelps [24] recognized five anatomical routes that could potentially lead to a temporal bone meningocele: (a) through the tegmen; (b) via a giant apical air cell; (c) via the Hyrtl's fissure; (d) via the petromastoid canal; and (e) via the labyrinthine segment of the fallopian canal.

Meningocele of fallopian canal thus represents a rare subtype of temporal bone meningocele, of which only 25 cases are reported in literature so far [1-16]. This condition appears to be related to a defective ossification process of the Facial Canal. The facial nerve and its canal embryologically derive from the second branchial arch, also known as Reichert cartilage. Particularly, the facial canal initially develops as a cartilaginous sulcus on the labyrinthine and tympanic portions of the otic capsule and, from the $34^{\text {th }}$ week of development, bone formation occurs, replacing the cartilaginous canal. In the late foetus and in the new-born, the fallopian canal is normally completely ossified. Incomplete ossification of the tympanic portion of the canal is a frequent occurrence, resulting in dehiscence in the tympanic portion of the facial nerve in up to 30 percent of temporal bones [11].

A tight sheath of dura extending laterally from the fundus of the IAC along the canal normally seals the facial nerve from the subarachnoid space. This seal is reinforced by the tight wall of the labyrinthine segment of the canal [17]. If this normally tight enclosure is abnormally large, the subarachnoid space may extend out to fill the enlargement.

Extensive clinical experience with facial nerve surgery has allowed Fisch et al to first hypothesize in 1977 that the subarachnoid space may extend into the geniculate ganglion [25]. Gacek examined the extension of the subarachnoid space within the fallopian canal in temporal bones and found the subarachnoid space extending distal to the geniculate ganglion in $4 \%$ of the temporal bones with subsequent widening of the fallopian canal and CSF leakage [17]. The constant pulsations of CSF, beyond a progressive stretching of facial nerve fibres without necessarily causing paralysis, may also cause erosion of surrounding bone eventually leading to fistulation [11]. 
The radiological diagnosis of middle ear meningocele is based both on HRCT and MRI. CT scan is excellent in defining anatomic relationships and bone destruction but does not show differences between a solid or cystic mass. In this regard, MR allows a precise tissue characterization. In case of fallopian canal meningocele the canal appears widened on CT scan and on MRI, a lesion presenting the same signal intensity of CSF is evident. Within the meningocele it is sometimes possible to identify the facial nerve, as shown in figure 2. Lesions such as facial nerve schwannoma, intratympanic meningioma and haemangioma present different radiological characteristics.

On CT scan it can be difficult to differentiate a temporal bone meningocele from a cholesteatoma, especially in patients who underwent previous otologic surgery. On MRI cholesteatomas appears hypointense in $\mathrm{T} 1$ weighted images, hyperintense on T2 and do not show gadolinium enhancement. Diffusion weighted images allows a differential diagnosis between meningocele and congenital cholesteatoma.

The main aim of surgical repair of temporal bone meningoencephalic herniations is to create a strong and definitive separation between middle ear cavity and endocranial contents in order to guarantee protection from new meningitis episodes [20].

There are several available treatment options. Asymptomatic meningoceles with no CSF leak may require no treatment $[8,17]$. When indicated, the surgical procedures can be carried out by a transmastoid approach, middle fossa approach and combined transmastoid/middle fossa approach [18].

While the surgical treatment of tegmen plate meningoceles is more codified [20], fallopian canal meningoceles represent a real surgical challenge. In contrast to meningocele coming from the MCF, in this specific case the meningeal sac comes from the IAC, therefore, in case of rupture, dural reconstruction is particularly complex.

Two main issues emerge from the analysis of the current literature: the first issue is whether or not such a lesion should be treated; the second question is which approach is better in order to stem the CSF leakage and isolate the meningocele from the middle ear cavity.
In the absence of any sign of CSF leakage, especially when the herniated sac is small and no other infection risk factors coexist like in the case in question, the better option could be avoiding any unreasonable manipulation of the meningocele, in consideration of the risk of iatrogenic CSF fistula or facial palsy. In our case a gentle covering of the sac by the use of autologous temporalis fascia was performed, in order to separate it from the middle ear space, as suggested by other Authors [8,13].

On the contrary, in case of CSF leakage the risks of facial paresis and recurrence of the leakage are very high. In these cases, a subtotal petrosectomy, sealing of the meningocele, mastoid obliteration and blind sac closure of the external auditory canal is probably the most effective and safest surgical solution, as demonstrated by our literature review. On the other hand, transmastoid approach is likely to be inadequate in terms of a full control of the geniculate ganglion area. Moreover, in case of MFC approach the IAC should be opened and followed up to its fundus, with a consistent risk of facial nerve paresis, meningitis or CSF leakage recurrence. In fact, almost all of the patients ( 5 of $7,71.43 \%$ ) approached by exclusive or combined MFC developed complications or recurrences (Table 1); hence, we would not indicate this procedure as first choice.

A last but not less important issue, not enough debated in the previous literature, is the strategy to adopt in case of bilateral fallopian canal meningocele. In our case, since the contralateral meningocele was small and asymptomatic, it was decided to only monitor it by a strict radiological follow-up, after proper pneumococcal vaccination and education of the patient. A similar approach was undertaken also by Allen., et al. (2013) [13].

\section{Conclusion}

Meningocele of the fallopian canal is a rare lesion originating from a congenital defect in the ossification of the fallopian canal.

Surgical treatment, which can be carried out using different approaches (transmastoid, MCF, combined, subtotal petrosectomy), must be tailored to the single case. MCF, however, is associated with higher risks of complications and recurrence.

In our case, considering the small size and the risk of iatrogenic CSF fistula or facial palsy, it was decided to exclusively seal the right meningocele with autologous temporalis fascia. Moreover, we have 
reason to believe that in case of bilateral presentation, especially with an asymptomatic side, it could be safe to undergo an exclusive strict clinical and radiological follow-up, after proper pneumococcal vaccination and education of the patient, who should be invited to request urgent aid in case of headache with fever.

\section{Competing Interests}

The authors have no conflicts of interest to declare.

\section{Funding Support}

This work received no specific grant from any funding agency in the public, commercial, or not-for-profit sectors.

\section{Acknowledgements}

We thank the patient for giving us her consent for publication. We thank Università di Bari for providing us all the scientific material for the review.

\section{Bibliography}

1. Harrington JW Jr and Birck HG. "Recurrent meningitis due to congenital petrous fistula. A case report". Archives of Otolaryngology 85.5 (1967): 572-575.

2. Gacek RR and Leipzig B. "Congenital cerebrospinal otorrhea”. Annals of Otology, Rhinology, and Laryngology 88.3-1 (1979): 358-365.

3. Barcz DV., et al. "Subarachnoid space: middle ear pathways and recurrent meningitis". American Journal of Otolaryngology 6.2 (1985): 157-163.

4. Legent F., et al. "Malformations du canal facial, méningite et otorrhée cérébro-spinale [Malformation of the facial canal, meningitis and cerebrospinal otorrhea]". Ann Otolaryngol Chir Cervicofac 106.3 (1989): 197-200.

5. Gray BG., et al. "Spontaneous meningocele, a rare middle ear mass". American Journal of Neuroradiology 16.1 (1995): 203207.

6. Petrus LV and Lo WW. "Spontaneous CSF otorrhea caused by abnormal development of the facial nerve canal". American Journal of Neuroradiology 20.2 (1999): 275-277.

7. Foyt D and Brackmann DE. "Cerebrospinal fluid otorrhea through a congenitally patent fallopian canal". Archives of Oto-
rhinolaryngology-Head and Neck Surgery 126.4 (2000): 540542.

8. Isaacson JE., et al. "Arachnoid cyst of the fallopian canal: a surgical challenge". Otology and Neurotology - LWW Journals 23.4 (2002): 589-593.

9. Van la Parra RF., et al. "An arachnoid cyst of the fallopian canal". Otology and Neurotology 28.8 (2007): 1153-1154.

10. Mong S., et al. "Fallopian canal meningocele: report of two cases". Otology and Neurotology 4 (2009): 525-528.

11. Dhanasekar G., et al. "Meningocoele of fallopian canal causing recurrent meningitis". The Journal of Laryngology and Otology 124.4 (2010): 460-462.

12. Zhang Q., et al. "Arachnoid cysts confined to the internal auditory canal or facial nerve canal". Journal of Laryngology and Otology 125.10 (2011): 1053-1058.

13. Allen KP and Roland PS. "Bilateral fallopian canal arachnoid cysts in a patient with spontaneous cerebrospinal fluid otorrhea". Otology and Neurotology 34.9 (2013): e128-129.

14. Teufert KB and Slattery WH. "Cerebrospinal fluid leak of the fallopian canal”. Ear, Nose and Throat Journal: SAGE Journals 92.3 (2013): E20-23.

15. Sagardoy T., et al. "Arachnoid cyst of the fallopian canal and geniculate ganglion area: our experience of 9 cases". Clinical Otolaryngology 42.2 (2017): 461-466.

16. Dey JK., et al. "Fallopian Canal Meningocele with Spontaneous Cerebrospinal Fluid Otorrhea: Case Report and Systematic Review of the Literature". World Neurosurgery 122 (2019): e285e290.

17. Gacek RR. "Anatomy and significance of the subarachnoid space in the fallopian canal". American Journal of Otolaryngology 19.3 (1998): 358-365.

18. Sanna M., et al. "Management of meningoencephalic herniation of the temporal bone: Personal experience and literature review". Laryngoscope 119.8 (2009): 1579-1585.

19. Wootten CT., et al. "Management of brain herniation and cerebrospinal fluid leak in revision chronic ear surgery". Laryngoscope 115.7 (2005): 1256-1261. 
20. Redaelli De Zinis LO. "Transmastoid repair of meningoencephalic herniation associated with cholesteatoma by canal wall-down procedure: our experience in eighteen patients". Clinical Otolaryngology 38.5 (2013): 397-402.

21. Vlastarakos PV., et al. "Efficacy assessment and complications of surgical management for superior semicircular canal dehiscence: a meta-analysis of published interventional studies". European Archives of Oto-Rhino-Laryngology 266.2 (2009): 177-186.

22. Gacek RR., et al. "Adult spontaneous cerebrospinal fluid otorrhea: diagnosis and management". American Journal of Otolaryngology 20.6 (1999): 770-776.

23. Rao AK., et al. "Diagnosis and management of spontaneous cerebrospinal fluid otorrhea". Otology and Neurotology 26.6 (2005): 1171-1175.

24. Phelps PD. "Congenital cerebrospinal fluid fistulae of the petrous temporal bone". Clinical Otolaryngology and Allied Sciences 11.2 (1986): 79-92.

25. Fisch U and Ruttner J. "Pathology of intratemporal tumors involving the facial nerve". In: Fisch U, ed. Facial Nerve Surgery: Proceedings of the Third International Symposium on Facial Nerve Surgery, 9-12 August 1976, Zürich, Switzerland. Amstelveen, The Netherlands: Kugler Medical Publications (1977): 449-456.

Volume 3 Issue 9 September 2021

(C) All rights are reserved by Vito Pontillo and Nicola Quaranta. 